PAEDAGOGIA CHRISTIANA

2/26(2010) - ISSN 1505-6872

Wojciech Hanc*

Warszawa-Włocławek

\title{
Dialog ekumeniczny - znaki nadziei dla chrześcijaństwa
}

Podejmowanie tematu odnoszącego się z jednej strony do ekumenicznego dialogu, a z drugiej do znaków nadziei dla nadal rozbitego chrześcijaństwa, będącego - jak powiada Dekret o ekumenizmie Soboru Watykańskiego II - podziałem jawnie sprzeciwiającym się woli Chrystusa i będącym zgorszeniem dla świata, a zarazem szkodzącym „najświętszej sprawie przepowiadania Ewangelii wszelkiemu stworzeniu" (DE 1) $)^{1}$, mogłoby się wydawać wręcz prowokacyjnym zabiegiem. A jednak mimo trudności, jakie na swej drodze napotykał i nadal spotyka ruch zjednoczeniowy od stu lat oraz od czterdziestu dialog ekumeniczny, szczególnie zintensyfikowany w ostatnich swoich etapach, skłania on - jak powiedział Jan Paweł II - do pójścia „naprzód drogą trudną, ale przynoszącą wiele radości - drogą jedności i komunii chrześcijan. Dialogi międzywyznaniowe na płaszczyźnie teologicznej przyniosły konkretne i widoczne owoce. I to właśnie zachęca, by tą drogą pójść dalej” (UUS 2). Papieżowi chodzi tu bez wattpienia „o pójście dalej z nadzieją" (zob. UUS 1, 4). Przy czym trzeba jednak pamiętać, by na prowadzone dialogi patrzeć oczyma wiary, bowiem to, co nie znalazło dotąd akceptacji dialogujących stron, pozostaje nadal jako problem otwarty albo jako wyrzut sumienia, iż podjęte dzieło nie zostało spełnione. Obliguje to do mobilizacji, by w kolejnych fazach prowadzonych rozmów wiele kwestii trudnych, dotąd nie rozwiązanych, znalazło swoje nowe naświetlenie czy

* Ks. dr hab. Wojciech Hanc, prof. UKSW, jest kierownikiem Katedry Ekumenizmu na Wydziale Teologicznym Uniwersytetu Kardynała Stefana Wyszyńskiego w Warszawie.

${ }^{1}$ Por. także encyklikę Jana Pawła II Ut unum sint (1995). Odtąd skrót: UUS z podaniem odnośnego numeru dokumentu, tutaj: UUS 6. 
wręcz uzyskało konsens dialogujących stron (por. DE 4, 9, 11; zob. Katechizm Kościoła Katolickiego, n. 821).

Skoro dzieło ekumeniczne zostało przez Kościół katolicki podjęte z nadzieją jako „imperatyw chrześcijańskiego sumienia oświeconego wiarą i kierowanego miłością", to nie mogą nie mieć tu zastosowania słowa Apostoła Narodów z Listu do Rzymian, iż „nadzieja zawieść nie może, ponieważ miłość Boża rozlana jest w sercach naszych przez Ducha Świętego, który został nam dany" (Rz 5, 5). Stąd, według Jana Pawła II, nadzieja jedności chrześcijan znajduje swoje Boskie źródło w jedności trynitarnej Ojca, Syna i Ducha Świętego (UUS 8). Nie dziwi przeto, iż już sam dialog ekumeniczny jako istotny element ekumenii i priorytet Kościoła (zob. DE 4; UUS 31) stanowi dla chrześcijaństwa szczególny znak czasu.

Oczywiste już dziś jest, że począwszy od II Soboru Watykańskiego Kościół katolicki wszedł nieodwołalnie na drogę ekumenicznych poszukiwań, czyniąc to szczególnie poprzez dialog doktrynalny, zdążając ku pełni prawdy, co znaczy, że Kościół wsłuchuje się w głos Ducha Pańskiego, który uczy go uważnie odczytywać „znaki czasu” (UUS 3). Dlatego nie sposób w tym miejscu nie wspomnieć - jeśli chcemy wskazać w odniesieniu do dialogu ekumeniczego na jakieś znaki nadziei dla chrześcijaństwa - jednego z wielkich propagatorów jedności, jakim był Jan XXIII, który w encyklice Pacem in terris $\mathrm{m}$. in. stwierdza, iż „,znaki czasu” nie stanowią czegoś przygodnego czy dodanego dla ubogacenia pewnych wydarzeń lub kwestii, lecz - jak powiada prekursor w tym względzie M. D. Chenu - powinny stać się podstawą dla konstruowania myśli. Zresztą każda z czterech części encykliki Jana XXIII kończy się wymienieniem znaków czasu, by mocno uwydatnić wartości ewangeliczne budzące się w toku dziejów, z czego nie można wyeliminować pragnienia jedności chrześcijan². Także II Sobór Watykański, a następnie Paweł VI i Jan Paweł II, w ślad za którymi poszło wielu katolickich teologów, w zakresie tzw. pozytywnych ,znaków czasu” wspierających Ewangelię, życie religijne i społeczno-kulturowe, wymieniają: rosnącą solidarność pomiędzy państwami i narodami, domaganie się prawa do wolności, sprawiedliwości i pokoju, zatroskanie o dzieło stworzenia i poszanowania przyrody, pełen dynamizmu rozwój młodych Kościołów, nowe możliwości i sposoby ewangelizacyjne, a nade wszystko dwudziestowieczny zryw ku chrześcijańskiej jedności, zwany ruchem ekumenicznym³ . Jeżeli więc teologia „znaków czasu” wybudowała pomost między „naturą" i „nadnaturą”,

2 To właśnie o tym wielkim Papieżu jedności wspomina M. D. Chenu w pozycji: Lud Boży w świecie, Kraków 1968, s. 37-38; por tenże, Les signes du temps, „Nouvelle revue théologique” 87 (1965), s. 29-39.

${ }^{3}$ Zob. C. Bartnik, Czym sq znaki czasu?, „Ateneum Kapłańskie” 150 (2008), z. 595, s. $425-427$. 
między dziejami ludzkimi a historią zbawienia, między światem a Kościo$ł^{4} \mathrm{em}^{4}$, to czy nie może stanowić równocześnie pomostu pomiędzy chrześcijańskimi tradycjami wyznaniowymi, prowadzącymi z sobą od ponad 40 lat doktrynalny dialog teologiczny, uwrażliwiający na fakt wspólnego braterstwa oraz tego, że więcej chrześcijan łączy niż dzieli, w czym oparciem są przecież dwie fundamentalne tajemnice: Misterium Trinitatis et Misterium Christi? Trzeba przeto powiedzieć, że ekumenizm w ogóle, a w szczególności dialog ekumeniczny, przy pomocy Bożego wsparcia, mogą z niemożliwego czynić możliwe, o czym będzie mowa poniżej. I choć droga dialogu jest trudna, żmudna i utkana wieloma przeszkodami, to nie można nie zgodzić się z proroczą wizją Jana Pawła II wyrażoną na kartach jego wiekopomnej encykliki „o działalności ekumenicznej”, iż właśnie ekumenizm stara się sprawić - w czym największą rolę pełni dialog ekumeniczny - usunięcie narosłych w dziejach rozbieżności tak doktrynalnych, jak i dyscyplinarnych, będących nadal przeszkodą dla pełnej komunii pomiędzy chrześcijanami (por. UUS 36). Zadaniem przeto prowadzących dialog jest, by „częściowa komunia istniejąca między chrześcijanami wzrastała ku pełnej komunii w prawdzie i miłości” (por. UUS 14).

W związku z powyższym rodzi się kilka pytań: czy trudna droga ekumenicznych zmagań dialogowych może rościć jakieś konkretne nadzieje na przyszłość? Czy wypracowanych ponad sto międzywyznaniowych dokumentów dialogowych i przynajmniej jeszcze raz tyle dokumentów lokalnych Wspólnot ${ }^{5}$ (poza jednym zaakceptowanym przez zwierzchności dialogujących Kościołów, a jest nim Wspólna Deklaracja w sprawie nauki o usprawiedliwieniu - Augsburg 1999) ${ }^{6}$, pozostanie li tylko dekoracyjnym elementem widniejącym na półkach ekumenistów i teologów? Czy będzie można wreszcie - posługując się słowami Jana Pawła II - „przekroczyć próg nadziei" w dialogu ekumenicznym? ${ }^{7}$ Oto niektóre tylko pytania, które jawią się przed zadanym autorowi tematem „o znaki nadziei dla chrześci-

${ }^{4}$ Zob. B. Przybylski, Znaki czasu, „Ateneum Kapłańskie” 74 (1970), z. 366, s. 134.

${ }^{5}$ Dysponujemy już dzisiaj kilkoma wydaniami zebranych razem dokumentów dialogowych - bilateralnych i multilateralnych w następujących językach: francuskim, angielskim, niemieckim i włoskim, mającymi rangę urzędowych wydań, czego przykładem niech będzie: H. Meyer, D. Papandreu, H. J. Urban, L. Fischer (hrsg.), Dokumente wachsender Übereinstimmung, Paderborn u. Frankfurt/M, Bd I 1983, Bd II 1992 (odtąd skrót: DwÜ z podaniem odnośnego tomu i strony) oraz G. Cereti i S. J. Voicu (red.), Enchiridion Oecumenicum. Documenti del dialogo teologico interconfessionale, t. 1-8, Bologna 1986-2007 (skrót: EOe z podaniem tomu i strony).

${ }^{6}$ Zob. K. Karski (red.), Deklaracja o usprawiedliwieniu: historia powstania, tekst deklaracji, opinie komentarze, Bielsko Biała 2000.

7 Zob. Przekroczyć próg nadziei. Jan Pawet II odpowiada na pytania Vittoria Messoriego, Lublin 1994, s. 116-122. 
jaństwa" na ekumenicznej drodze rozmów i „urzędowego czyli oficjalnego" dialogu.

Wreszcie wydaje się być dość ważne w tej wprowadzającej części uświadomienie sobie faktu, iż oficjalny dialog został uprzedzony wcześniejszymi rozmowami bilateralnymi, czego wyrazem stały się rozmowy pomiędzy anglikanami i prawosławnymi, anglikanami i starokatolikami, starokatolikami i prawosławnymi, co już na tamtym etapie zaowocowało pewnymi wynikami pozytywnymi. Ponadto nie można nie zauważyć, śledząc historię prowadzonych rozmów międzywyznaniowych, iż ruch ekumeniczny pierwszej połowy XX wieku, postrzegany w jego całości, wypływał z innych uwarunkowań, gdyż chodziło o osiagnięcie przynajmniej pewnej wspólnoty na tamtym, wstępnym etapie jego prowadzenia, stanowiąc przedpole dla osiagnięcia jedności $\mathrm{w}$ daleko szerszym zakresie, czego wyrazem było powstanie w Amsterdamie (1948) Ekumenicznej Rady Kościołów ${ }^{8}$. Jednak od tamtego wydarzenia, czyli po ponad 60 latach, prowadzone na różnych płaszczyznach wielostronne i dwustronne dialogi pomiędzy różnymi tradycjami wyznaniowymi zaczęły nie tylko stawać $\mathrm{w}$ centrum uwagi zjednoczeniowych poczynań, lecz spowodowały rozpoczęcie całej sieci przeróżnych dialogów, które w ich intensyfikacji i rozwoju, a przede wszystkim w osiagniętych wynikach, zmuszają dziś do pochylania się specjalistów i ekspertów ekumenicznych nad ponad stu dokumentami, które nadal czekają na recepcję najwyższych gremiów kościelnych. Mając przeto na uwadze wspomniany już wyżej fakt, iż dialog ekumeniczny stanowi istotny element współczesnych zabiegów zjednoczeniowych, a zarazem „węzeł gordyjski” ekumenii, stanowiący o jej „być albo nie być”, oraz to, że często przeżywa on różnorakie trudności i przestoje, zapytajmy ponownie: czy w ogóle można wskazać przynajmniej na pewne przebłyski nadziei na przyszłość, iż trud wielu powoływanych komisji dialogowych w przeszłości i teraźniejszości nie pójdzie w zapomnienie czy wręcz w beznadzieję? Dlatego niniejsze opracowanie zwróci uwagę li tylko przykładowo na niektóre przyczynki, znaczone nadzieją na lepszą pod tym względem ekumeniczną przyszłość.

\section{Komunikacja świętych męczenników z Bogiem i ludźmi - znakiem nadziei na pojednanie chrześcijan}

Każdy ze świętych, zarówno kanonizowanych i beatyfikowanych, jak i zwyczajnych ludzi realizujących heroizm wiary, nadziei i miłości, nosi w sobie „nasienie męczeństwa”. Stąd Jan Paweł II przygotowując Kościół

${ }^{8}$ Por. DwÜ 1, s. 12. 
rzymskokatolicki do obchodów jubileuszu roku 2000, świadom okrucieństwa spowodowanego przez dwie światowe wojny, a zarazem deptania w okresie ponad 70 lat panowania totalitarnych systemów ludzkiej godności, gdzie sztucznie podtrzymywane podziały dochodziły wręcz do absurdalnych rozmiarów, podczas całego pontyfikatu nie mógł nie wspominać o tych, którzy cierpieli z powodu Ewangelii, bez względu na wyznaniową przynależność. Dał temu m.in. wyraz w liście apostolskim Tertio millennio adveniente ${ }^{9}$, w którym pisze, iż Kościół pierwszego tysiąclecia zrodził się z krwi męczenników: sanguis martyrum - semen christianorum, cytując słowa Tertuliana z jego dzieła Apologeticus (50,13), które ciaggle są aktualne, gdyż i

u kresu drugiego tysiąclecia Kościół znowu stał się Kościołem męczenników. Prześladowania ludzi wierzących [...] zaowocowały wielkim posiewem męczenników w różnych częściach świata. Świadectwo dawane Chrystusowi, aż do przelania krwi, stało się wspólnym dziedzictwem zarówno katolików, jak prawosławnych, anglikanów i protestantów. [...] To świadectwo nie może być zapomniane [...]. W naszym stuleciu wrócili męczennicy (TMA 37).

W ujęciu Papieża ma to szczególny charakter i wymowę ekumeniczną, bowiem ów ekumenizm świętych jest najbardziej przekonujący (tamże). Skoro już w II wieku ,krew męczenników stała się nasieniem chrześcijan”, to nie może być truizmem ani przesadnym wyrazem dewocji zwrócenie uwagi na ten ekumeniczny fakt w czasach współczesnych, czyli męczeństwa fizycznego lub moralnego - znaków chrześcijańskiej nadziei, czego wyrazem jest także współcześnie akceptowana przez parlamenty dewastacja symboli religijnych, a szczególnie krzyża - niezwykłego znaku chrześcijańskiej nadziei. Dlatego nie dziwi, że rozwijający się po II wojnie światowej ruch ekumeniczny wpisuje w swoją istotną treść i zakres męczeństwo chrześcijan, o którym Jan Paweł II w encyklice Ut unum sint ${ }^{10}$ aż czterokrotnie wspomina, że

odważne świadectwo licznych męczenników naszego stulecia, należących do innych także Kościołów i Wspólnot kościelnych, które nie są w pełnej komunii z Kościołem katolickim, nadaje nową moc wezwaniu Soboru [...], bowiem

${ }^{9}$ List apostolski Tertio millennio adveniente ogłoszony w związku z przygotowaniem jubileuszu roku 2000 (10 XI 1994) zawiera się w zbiorze: Listy pasterskie Ojca Świętego Jana Pawła II, Kraków 1997, s. 9-56. Odtąd skrót: TMA z podaniem odnośnego numeru dokumentu.

10 Jest to magna charta współczesnej ekumenii, jeszcze w pełni niezgłębiona, zwana także przez ekumenistów ,wielką kartą dialogu”, opublikowaną 25 maja 1965 r. Tekst polski encykliki „o działalności ekumenicznej” zawiera się w: Encykliki Ojca Świętego Jana Pawła II, Kraków 1996, s. 989-1077. 
ci nasi bracia i siostry, połączeni przez wielkoduszną ofiarę z własnego życia, złożoną dla Królestwa Bożego, są najbardziej wymownym świadectwem tego, iż można przekroczyć i przezwyciężyć wszelkie elementy podziału, składając całkowity dar z siebie dla sprawy Ewangelii (UUS 1).

Następnie Papież wspominając, ,pierwiastki uświęcenia i prawdy, które w różnych Kościołach i Wspólnotach są obecne i działają poza widzialnymi granicami Kościoła katolickiego” - wymienia także „prawdziwą więź w Duchu Świętym”, gdyż Trzecia Boska Osoba przez wszystkich chrześcijan uznawana za „duszę” ekumenii, ,przez swe łaski i dary pośród nich działa także swą uświęcającą mocą, a niektórym spośród nich dał nawet siłę do przelania krwi” (UUS 12). W mocy Ducha Bożego Jan Paweł II postrzega rozbudzenie tęsknoty i działanie przypieczętowane męczeństwem, by wszyscy mogli zjednoczyć się w pokoju (por. tamże). Owo świadectwo dawane „aż do przelania krwi” to, według Papieża, ogromny obszar dla całego ekumenicznego doświadczenia, w tym także na polu ekumenicznego dialogu, co stanowi szczególne wyzwanie wobec naszej epoki (zob. UUS 48). Dlatego ekumenizm męczenników jest ze wszystkich jego wymiarów najbardziej przekonywujący, ponieważ wskazuje drogę ku jedności będącej bezpośrednim dziedzictwem krzyża, przeżywanego wyłącznie w kontekście Jezusowej prawdy ${ }^{11}$. Stąd w teocentrycznej perspektywie chrześcijanie mają już wspólne martyrologium, które obejmuje także licznych męczenników naszego stulecia. Martyrologium to ,jest świadectwem, że na pewnym głębokim poziomie Bóg utrzymuje między ochrzczonymi komunię w wierności najwyższemu nakazowi wiary, jaka się objawia w ofierze życia” (UUS 84). Święci wywodzą się z wszystkich Kościołów i Wspólnot kościelnych, które otworzyły im drogę do korzeni zbawienia. To oni stanowią dowód na moc łaski, która objawia się w męczeństwie aż do śmierci, w owej najprawdziwszej realistycznej komunii z Chrystusem, który, według Apostoła Narodów (por. Ef 2,13), rozlewa własną krew i przez tę ofiarę przybliża ku sobie tych, którzy niegdyś byli daleko (UUS 84). To męczennicy, których łączy ta sama wiara, mimo iż pochodzą z różnych wyznaniowych tradycji, budują pomost między Kościołami i kościelnymi Wspólnotami. Jednocześnie zaś odwoływanie się do ich świadectwa wiary ubogaca chrześcijan różnych konfesji ${ }^{12}$. Właśnie w tym miejscu chciałoby się sparafrazować Tertulianową sentencję, iż krew męczenników stanowi nasienie dla chrześcijan bez

${ }^{11}$ Por. Jan Paweł II, Homilia: Nigdy nie ulękli sięprzed mocq zła, „L'Ossevatore Romano” 21 (2000), nr 7-8, s. 33.

12 Por. T. Siuda, Duszpasterstwo ekumeniczne w archidiecezji poznańskiej, w: J. Budniak (red.), Ekumenizm w duszpasterstwie parafialnym, Katowice 2007, s. 140. 
względu na denominacyjną przynależność. Są to po prostu znaki nadziei dla urzeczywistnianego przez nich dialogu miłości i pojednania. Dla ekumenistów jest przeto czymś oczywistym, iż święci nie mogą dzielić, bowiem są wzorem i przykładem do naśladowania ${ }^{13}$. Według prof. A. Naumowa, przynależącego do Kościoła prawosławnego, a zarazem slawisty, cześć oddawana świętym, zwłaszcza współczesnym, jest projekcją określonych potrzeb czy oczekiwań Kościołów. Mają swoje transcendentne odniesienie, a jednocześnie są bardzo mocno wrośnięci w historię, w sprawy doczesne, chociaż bardzo rzadko czynili to z własnej woli i inicjatywy. I dalej, niektórzy święci stali się symbolami jedności wielu narodów. Po prostu ,prawosławni wierzą, że święci jako specjalna kategoria sprawiedliwych, po śmierci znajdują się w niebie [...], że są pośrednikami i orędownikami między ludźmi i Bogiem, że wysłuchują próśb ludzkich i w modlitwach zanoszą je przed Pana"14. Na pytanie zaś, czy święci łączą czy dzielą, Profesor odpowiada na obydwa pytania twierdząco. Łączą bowiem „Kościół dawniej wojujący, dziś pielgrzymujący, z Kościołem Chwały, łączą człowieczeństwo z boskością, przemijalność historii z wieczną ponadczasowością zbawienia. Łączą Lud Boży, by za ich przyczyną wielbił Tego, który ich do świętości powołał, by byli stawiani za wzór wobec wiernych". Dlaczego więc dzielą? Dzielą tym, ,z czego Bóg pozwolił im się otrząsnąc - historią”, swoim genetycznym powiązaniem z ziemską rzeczywistością. Według A. Naumowa, „to Kościół jako instytucja ziemska sprowadza nieraz ów mistyczny wymiar świętości do historycznego czy politycznego konkretu"15. Nie ulega wattpliwości, iż perspektywa ekumeniczna w refleksji Profesora Naumowa szczególnie dochodzi do głosu, bowiem swoje dywagacje popiera przykładami świętych, zwłaszcza męczenników, wyniesionych do chwały, a wywodzących się z różnych Kościołów, co nie znaczy, by nie uwydatniać różnic wyznaniowych w tym względzie ${ }^{16}$. W ekumenii jest to czymś normalnym, gdyż zwłaszcza w dialogu należy mówić o tym, co chrześcijanie uważają za wspólne dziedzictwo, jak i o tym, czym się pomiędzy sobą różnią.

Podobne stanowisko jest zajmowane w teologiczno-ekumenicznej refleksji ewangelickiej, która także podkreśla ekumeniczny wymiar problemu czci świętych, przytaczając jako potwierdzenie dialogi doktrynalne katolic-

${ }_{13}$ Zob. R. Mikler, Wstęp, w: Z. J. Kijas (red.), Święci a pojednanie Kościołów. Święci łaczq czy dzielq?, Kraków 1998, s. 9-12.

${ }_{14}$ A. Naumow, Święci łaczq czy dziela? Perspektywa prawosławna, w: Z. J. Kijas (red.), dz. cyt., s. 78 .

15 Tamże, s. 79.

${ }_{16}$ Zob. tamże, s. 78-80. 
ko-luterańskie i katolicko-zielonoświątkowe ${ }^{17}$. Nie wchodząc w dialogowe stanowiska, warto zwrócić uwagę na niezwykle cenną w tym względzie sentencję, wypowiedzianą przez K. Bartha, jednego z najwybitniejszych teologów Kościoła ewangelicko-reformowanego, i w ogóle teologa ewangelickiego XX wieku, z którym dość często dialogował Jan Paweł II. Oto treść jego wypowiedzi:

Prawo przynależności do jednej «społeczności świętych» mają nie tylko żyjący aktualnie, ale i umarli; nie tylko współcześnie żyjący, ale i ci, którzy ich poprzedzili, wraz z nimi notorycznie wypowiadają swoje słowa i czynią swoje dzieła; ich historia nie kończy się bynajmniej wraz z zejściem z tego świata; dosyć często dzieje się tak, że ich historia dopiero długi czas po śmierci, pośród ich potomków osiąga decydujące stadium, wchodzą w trwały związek z każdorazową teraźniejszością ${ }^{18}$.

I choć powyższej konkluzji nie wypowiedział wyżej cytowany teolog ewangelicki, to można skonkludować, że w takim patrzeniu na świętych, w tym rzymskich katolików, święci jawią się jako jasne promienie dla przyszłości chrześcijaństwa i kontynuacji trudnego dialogu ekumenicznego, choć wydawać by się mogło, iż w tak szczegółowej tematyce tyczącej się świętych łączy wszystkich chrześcijan jedno wielkie communio sanctorum, których bez względu na terminologię należy uważać za „upamiętniających świadków wiary", wiary wspólnej w moc przepowiadanego Bożego słowa. W refleksji prof. K. Karskiego protestantyzm dopuszcza wspominanie świętych, o ile służy ono zilustrowaniu wiary w Chrystusa, wzmocnieniu słabych $\mathrm{w}$ wierze oraz dodawaniu otuchy Jego naśladowcom poprzez wskazywanie na ich żarliwą wiarę, głęboką miłość, niezwykłą cierpliwość, wytrwałość i bohaterstwo [...], dostrzega się rolę świętych jako wzoru dla własnego życia wiary" "19, w tym także w sensowność dialogu ekumenicznego, branego w wąskim i szerokim jego ujmowaniu. Ekumenizm bowiem świętych (męczenników) jest najbardziej przekonywujący. Wymieńmy więc spośród całego ekumenicznego martyrologium choćby takie osobowości, jak: Lambert Beauduin, Martin Bucer, Grzegorz Palmas, Paul Irénée Couturier, Jan XXIII,

17 Zob. K. Karski, Kościoły protestanckie a kult świętych, w: Z. J. Kijas (red.), dz. cyt., s. $99-101$.

${ }_{18}$ Cyt. za: K. Karski, dz. cyt., s. 98.

19 Tamże, s. 102. 
Jan Paweł II, Dietrich Bonhoeffer ${ }^{20}$ czy Roger Schutz z Taizée ${ }^{21}$. Oto jedynie kilka osobowych przykładów, będących znakami nadziei dla chrześcijaństwa, a zarazem wielkich świadków Ewangelii i ekumenii. Niezależnie więc od konfesyjnej przynależności, święci, a zwłaszcza męczennicy, pokazują światu, że chrześcijańska egzystencja oznacza w rzeczywistości bycie i ofiarę składaną na rzecz innych. To święci męczennicy tworzą niepojęte communio sanctorum, zapraszając do gromadzenia się i pojednania wokół Chrystusa $^{22}$. Święci tworzą prawdziwą, a zarazem nieprzemijającą historię, pisaną ponad wszelkimi podziałami, a czynią to poprzez swój nieustannie prowadzony dialog życia z Ojcem przez Chrystusa w Duchu Świętym. Dlatego ich świadectwo budowania jedności opartej o Trójjedynego Boga jest z jednej strony jej widzialnym znakiem, z drugiej zaś same wspomnienia owych świadków wiary są budowaniem mocnych fundamentów nadziei, która ożywiać będzie wiarę przyszłych pokoleń23 ${ }^{23}$ Nie dziwi przeto stwierdzenie Jana Pawła II już wyżej sygnalizowane, a zapisane na kartach Tertio millennio adveniente, iż „Chyba najbardziej przekonywujący jest [...] «ekumenizm świętych» męczenników. Communnio sanctorum mówi głośniej aniżeli podziały" (TMA 37). Fenomen chrześcijaństwa sprawia, że wyznający tego samego Boga, bez względu na rozbieżności doktrynalne, których się jeszcze nie udało w dialogu wyeliminować, traktują męczeństwo jako owoc „życia w Chrystusie”, jako doskonałe przebóstwienie lub rzeczywistą wolność i usprawiedliwienie, a przez to potwierdzają fakt niezwykłej wierności Ewangelii oraz ścisłej więzi z Chrystusem.

${ }^{20}$ Zwrócić warto uwagę na niezwykłość postawy Dietricha Bonhoeffera, który w niemieckim obozie koncentracyjnym stał się męczennikiem za udział w spisku politycznym. Według Eberharda Bethge, jego dzieło i życie tworzą pomost pomiędzy zwaśnionymi krajami i blokami, pomiędzy poróżnionymi konfesjami, przy czym dopiero 10 lat po śmierci teologa uwidoczniło się jego oddziaływanie na innych. Por. E. Bethge, Dietrich Bonhoeffer, Bielsko-Biała 1996, s. 7-9. D. Bonhoeffer zginą 9 kwietnia przez powieszenie w Flossenburgu. To o nim W. A. Visser'Hooft, długoletni sekretarz generalny ŚRK, powiedział m. in., iż „nauczyłem się więcej zjego pytań, niż on z moich odpowiedzi”, E. Bethge, dz. cyt., s. 137; zaś Reinhold Niebuhr, jeden z wybitnych teologów protestanckich w USA, stwierdza: „Nie tylko jego męczeńska śmierć, lecz również jego czyny i koncepcje niosą nadzieję na odrodzenie nowego sposobu przeżywania wiary protestanckiej w Niemczech. Będzie to wiara o wiele głębsza od wiary wielu spośród jego krytyków", E. Bethge, dz. cyt., s. 138-139.

${ }^{21}$ Zob. T. Siuda, dz. cyt., s. 141.

${ }^{22}$ Zob. A. Nossol, Teologia bliższa życiu, Opole 1984, s. 328-330.

${ }^{23}$ Por. Jan Paweł II, Ekumenizm męczenników. Rozważanie przed modlitwa ,, Regina coeli”, „L'Osservatore Romano” 21 (2000), nr 7-8, s. 32. 


\section{Dialog ekumeniczny wpisany ,w serce ekumenii” - znakiem nadziei i szansą dla chrześcijaństwa}

Jan Paweł II w ekumenię czasów współczesnych, przenikniętą krwią męczenników na rzecz jedności, wpisał dialog jako podstawową kategorię eklezjologiczna, włączając go zarazem w wizję jednania. Idąc za wskazaniami II Soboru Watykańskiego, chciał uczynić z niego postawę dialogiczną, czyli proces włączony zarówno w sferę poznania (dia-logos), jak i w kościelną praxis, pokazując swoimi licznymi pielgrzymkami, spotkaniami i inicjatywami obraz Kościoła otwartego ze swej natury na świat i na ludzi inaczej wierzących. Dialog bowiem posiada wymiar całościowy, angażując cały ludzki podmiot oraz całą podmiotowość Wspólnot, do których przynależą jednostki. Dialog to nie tylko wymiana myśli, lecz w jakiś sposób jest to również „wymiana darów” (UUS 28) ${ }^{24}$. I właśnie tak pojmowany dialog w sposób najbardziej dojrzały urzeczywistnia się w ekumenii, przez co chrześcijaństwo otrzymuje niezwykłą szansę, wpisaną w plany zbawcze ruchu ekumenicznego (2.1). Przy czym szczególnym tego wyrazem są owoce doktrynalnego dialogu ekumenicznego w postaci ponad stu wypracowanych dokumentów, które jedynie egzemplarycznie zostaną tu wspomniane (2.2).

\subsection{Wieloimienność dialogu ekumenicznego}

Ekumeniczny dialog ma niejedno imię. By się o tym przekonać, wystarczy wziąć do ręki soborowy Dekret Unitatis redintegratio (1964) i encyklikę Jana Pawła II Ut unum sint (1995). W dokumencie pierwszym (zob. DE 4) dialog został jedynie zasygnalizowany i w pewnym ogólnym sensie zarysowany, choć nie ograniczony li tylko do doktrynalnego wymiaru. Natomiast papieska encyklika, poświęcona w całości działalności ekumenicznej, uwydatnia dialog jako proces, który w różnych płaszczyznach powinien się wpisywać w samo „serce” ekumenii jako znak czasu, a zarazem jako konieczność, która: 1) ma zwracać uwagę na liczne elementy wielkiej wartości (eximia), które znajdują się także w innych Wspólnotach chrześcijańskich (zob. UUS 13);2) ma dostrzegać w dialogach nie tylko wyjątkowe narzędzie stymulujące ekumeniczne dążenia, lecz przede wszystkim świadectwo tego, co zostało już dokonane jako podstawa dla dalszych poszukiwań i badań, które należy kontynuować i pogłębiać, co po dziesiątkach lat dialogowej in-

${ }^{24}$ Por. R. E. Rogowski, ,, Ut unum sint” w świetle wspótczesnej kultury dialogu, w: P. Jaskóła (red.), Perspektywy jedności, Opole 1996, s. 12. 
tensyfikacji napawa nadzieją na dalsze postępy i osiągnięcia (zob. UUS 17). Przy czym dialog - kiedy mówimy, że ma niejedno imię - nie może być ograniczany do sfery uzgodnień teologicznych, choć doktryna i sposób jej przedstawiania posiada tu zasadnicze znaczenie (zob. UUS 18-19).

By jednak można było mówić o dialogu ekumenicznym jako procesie rokującym nadzieje, należy go przede wszystkim urzeczywistniać w dwu zasadniczych płaszczyznach: 1) w płaszczyźnie horyzontalnej odnoszącej się do spotkań, wymiany myśli czy wymiany darów; 2) w płaszczyźnie wertykalnej, polegającej na wspólnym i wzajemnym uznaniu naszej kondycji jako ludzi, którzy zgrzeszyli (UUS 35). Obydwie wymienione płaszczyzny są dla całościowego zaistnienia dialogu niezbędne, wzajemnie się dopełniające i warunkujące, co otwiera przed chrześcijanami ową wewnętrzną przestrzeń, nawet w odniesieniu do osób, z którymi nie mamy pełnej komunii, bowiem i wtedy Chrystus, będący źródłem jedności, może skutecznie działać mocą swego Ducha Pocieszyciela (tamże) ${ }^{25}$. I dalej, skoro dialog ma pełnić zadanie swoistego stymulatora we wspólnym szukaniu i dochodzeniu do prawdy, kształtującej sumienia i czyny chrześcijan, to powinien on spełniać zarazem funkcję swoistego rachunku sumienia, przejawiającą się w radykalnym „wzywaniu do uznania własnej grzeszności, co powinno wpływać istotnie na całokształt ducha ekumenicznego dialogu jako takiego" (por. UUS 34). Jeżeli dialog ma być znakiem nadziei i szansą dla chrześcijaństwa, to nie można stracić z pola widzenia czegoś bardzo ważnego, a mianowicie ,pokornej świadomości, że wszyscy zgrzeszyliśmy przeciwko jedności” oraz przekonania, że potrzebujemy nawrócenia (tamże). Potrzebny jest więc także „dialog nawrócenia”, gdyż jak mówił już o tym papież Paweł VI w swej programowej encyklice Ecclesiam suam (1964) - staje się on jednocześnie „dialogiem zbawienia”. „Dialog nawrócenia” powinien płynać z chrześcijańskiego pragnienia odbudowania utraconej jedności, co z kolei ma polegać na głębszym przylgnięciu do Ewangelii, a więc do fundamentu jedności, czyli do Chrystusa. Nie należy się więc dziwić, że dla Jana Pawła II droga kładąca kres podziałom jest nader prosta i przejrzysta, iż jednocząc się coraz intensywniej z Chrystusem, stajemy się tym samym ściślej zjednoczeni pomiędzy sobą ${ }^{26}$. Przy czym według Jana Pawła II „,szlak nawrócenia serca jest wyznaczony rytmem miłości, która zwraca się równocześnie do Boga i do braci, wszystkich bez wyjątku" (UUS 21). Być może dlatego Kościoły dość często obejmują dialog miłości wyrażeniem ,,wspólnego przebywania w mi-

25 Zob. W. Hanc, Ekumeniczny wymiar sakramentów chrześcijańskiej inicjacji w świetle międzywyznaniowych dialogów doktrynalnych. Studium ekumeniczne, Włocławek 2003, s. 55-57.

26 Por. A. Skowronek, Odkrywanie jedności, Warszawa 1988, s. 220. 
łości”, czego przykładem mogą być braterskie relacje pomiędzy Watykanem a Konstantynopolem czy Watykanem a Jerozolimą (zob. UUS 52-53) ${ }^{27}$.

W świetle całej gamy różnorodnych sformułowań odnoszących się do dialogu ekumenicznego narzuca się wręcz postulat ich komplementarnego traktowania. Wspomniane wyżej sformułowania: „dialog doktrynalny”, „dialog jako rachunek sumienia”, „dialog nawrócenia”, „dialog zbawienia” czy „dialog miłości” wskazują na szerokie spectrum dialogu, obejmującego zarówno jego wymiar doktrynalny, jak i praktyczny, przy czym obydwa powinny prowadzić ku pełni egzystencji w jednym, świętym, katolickim i apostolskim Kościele Jezusa Chrystusa, o czym nie sposób tu nie wspomnieć. Dał zresztą temu wyraz już ponad 40 lat temu jeden z najwybitniejszych teologów ewangelickich XX wieku - Karol Barth (zm. 1968) ${ }^{28}$. Dialog bowiem ekumeniczny jest z natury swojej sprawą całego Kościoła, stąd jego istotną płaszczyzną będzie Kościół założony przez Jezusa Chrystusa, postrzegany w swoich różnorakich obrazach, czyli ujmowany w jego bosko-ludzkiej rzeczywistości, co odnosi się tak do dialogu teologicznego (doktrynalnego), czyli do sfery eklezjologicznej, jak i do wszelkich innych jego form, w tym do jego rzeczywistości duchowej, widzialnej, czyli także instytucjonalnej, w co powinny być wtopione relacje do człowieka i świata, czemu dała wyraz soborowa Konstytucja Gaudium et spes ${ }^{29}$. Dlatego dialog ekumeniczny wyżej zarysowany, rozszerzony co do zakresu, stanowi niezastąpioną płaszczyznę chrześcijańskiej egzystencji, w tym przede wszystkim rzeczywistości Kościoła, zaś w ekumenii jest sprawą wyjątkowej wagi. Dialog to po prostu przywilej naszych czasów, czego nie wolno nie docenić czy wręcz zmarnować. Zdawał sobie z tego sprawę Jan Paweł II, stąd w samo serce ekumenii wpisał dialog, bez którego nie byłoby postępów na drodze zjednoczeniowej. Szczególnym zaś wyrazem tego są dialogi doktrynalne, prowadzone zarówno w płaszczyźnie międzynarodowej, jak i lokalnej ${ }^{30}$. To one „zapisały całe stronice - powiada Jan Paweł II - naszej «Księgi jedności» - Księgi, którą winniśmy nieustannie przeglądać i na nowo odczytywać, aby czerpać z niej natchnienie i nadzieję" (UUS 15).

27 Zob. W. Hanc, dz. cyt., s. 57-58.

${ }^{28}$ Zob. K. Barth, Ad limina apostolorum, Berlin 1967, s. 17.

${ }^{29}$ Por. W. Hanc, dz. cyt., s. 54-55.

${ }^{30}$ Zob. przypis nr 5 . 


\subsection{Owoce i recepcja ekumenicznych dialogów jako signa prognostica}

Szczególnym rodzajem dialogu ekumenicznego jest dialog doktrynalny, bez którego postępy na drodze zjednoczeniowej byłyby znikome. Fakt, iż dysponujemy dziś liczbą ponad stu uzgodnionych raportów, oświadczeń i deklaracji, świadczy o znaczącym postępie, czynionym przez Kościoły i Wspólnoty kościelne w liczącym już dziś sobie 100 lat ruchu ekumenicznym (początek miał miejsce w Edynburgu w 1910 r.). Dokonane uzgodnienia, jako wynik multilateralnych i bilateralnych dialogów, stanowią konkretne owoce, tak bardzo potrzebne w drodze ku pełnej eklezjalnej i eucharystycznej komunii; powiedzieć trzeba więcej, iż są to signa prognostica ${ }^{31}$, zapowiadające ów niezwykły dzień pełnej jedności, o czym przypomniał Jan Paweł II w liście do kardynała Waltera Kaspera, przewodniczącego Papieskiej Rady do Spraw Jedności Chrześcijan. List był związany z obradami na temat duchowości ekumenicznej zgromadzenia plenarnego powyższej Rady ${ }^{32}$. Oto fragment potwierdzający ową perspektywę jedności (zob. List, n. 3) połączoną z nadzieją: „Niczym latarnia wskazująca drogę w mrok podziałów odziedziczonych po wielu stuleciach, w których popełniano grzechy przeciw jedności, niezłomna pozostaje nadzieja, że Duch Chrystusa będzie nas wspierał w tej drodze, lecząc nasze słabości i zaniedbania, ucząc nas realizować w pełni przykazanie miłości $(\mathrm{J} 13,15)$ ", co usposabia do słuchania, d i a log u (podkr. W. H.), nawrócenia i odnowy (List, n. 4).

Pytanie o osiagnięte $\mathrm{w}$ ciagu ostatniego pięćdziesięciolecia owoce dialogowania skłania każdego (kto by zechciał włączyć dialog w owe signa prognostica patrząc z nadzieją w przyszłość i to niekoniecznie czekając na czasy ostateczne, które przecież już się urzeczywistniają) do ponownego sięgnięcia do encykliki Ut unum sint, zwłaszcza do jej drugiego rozdziału.

Papież nie ukrywa radości, iż ,po raz pierwszy w dziejach została podjęta działalność na rzecz zjednoczenia chrześcijan w tak rozległym zakresie", za co składa on dziękczynienie Duchowi Prawdy, który uczynił ruch ekumeniczny narzędziem w swoich rękach (por. UUS 41). Zbierając zaś w całość dialogowe osiagnięcia, co samo z siebie podkreśla znaczenie i ran-

${ }^{31}$ Termin ten odnosi się zasadniczo do sakramentalnych znaków, m. in. do ich funkcji prognostycznej, gdyż zapowiadają zbawienie eschatyczne i do niego przygotowują; zob. S. C. Napiórkowski, Z Chrystusem w znakach, Niepokalanów 1995, s. 66. Tutaj bierzemy to sformułowanie w szerszej jego aplikacji.

${ }^{32}$ List opublikowała red. polska „L'Osservatore Romano” 25 (2004), nr 3, s. 10-11; zob. „Biuletyn Ekumeniczny” 1 (2004), s. 5-8. List i zawarte w nim przesłanie pochodzi z 30 XI 2003 r. Odczytał go zgromadzonym uczestnikom kard. W. Kasper. Odtąd skrót: List z podaniem odnośnego numeru. 
gę ekumenicznego dialogu, należy choćby zwrócić uwagę na kilka ważnych momentów: 1) na poczucie wśród chrześcijan odzyskanego braterstwa, które stało się trwałym elementem ekumenicznej świadomości (zob. UUS 41-42); 2) na solidarność w służbie ludzkości, bowiem w pewnych okolicznościach wspólny głos chrześcijan, według Papieża, silniej oddziałuje niż odosobniony; 3) na fakt, iż „liczni chrześcijanie wszystkich Wspólnot, powodowani swoją wiarą, uczestniczą razem w śmiałych przedsięwzięciach, które stawiają sobie za cel przemianę świata, tak aby zwyciężył w nim szacunek dla praw i potrzeb wszystkich" (UUS 43); 4) na zbieżności w dziedzinie słowa Bożego i liturgicznego kultu, o czym mogą świadczyć ekumeniczne przekłady Biblii, czy podjęte troski o odnowę swego kultu (UUS 45-46); 5) na uznanie dla dóbr istniejących u innych chrześcijan, co stanowi niezwykle bogaty w łaskę potencjał ekumeniczny (zob. UUS 47-48); 6) na skutek bilateralnych dialogów w postaci wzrostu komunii (UUS 49), zwłaszcza z Kościołami Wschodu (zob. UUS 50-51). Kontynuowany jest także proces wzajemnej otwartości (por. UUS 52-54) poprzez nawiązanie dialogu teologicznego pomiędzy Kościołem katolickim a wszystkimi Kościołami prawosławnymi związanymi z Konstantynopolem (UUS 52).

Zwrócona została przeto uwaga na wspólny cel, jakim jest odnalezienie pełnej komunii z Kościołami siostrzanymi z zachowaniem uprawnionej różnorodności (por. UUS 55-61). Nie pominięto wzajemnych relacji ze starożytnymi Kościołami Wschodu (UUS 62-63), które kiedyś zakwestionowały formuły dogmatyczne soborów: efeskiego i chalcedońskiego, oraz z Kościołami i kościelnymi Wspólnotami na Zachodzie (UUS 64-70), żywiącymi szczególną miłość i cześć dla Pisma Świętego, mającymi z nami wspólny chrzest wszczepiający w Kościół. Wreszcie zostały podkreślone i inne relacje eklezjalne, jak np. spotkania, wspólna modlitwa czy innego typu współdziałanie, czemu dawały wyraz papieskie podróże (UUS 70-73). Wszystko to prowadziło do wzrostu komunii uczuć i działań (UUS 77).

Mimo wszystko przed chrześcijaństwem nadal stoi jeszcze długa droga ku pełnej jedności wszystkich ochrzczonych i wierzących w Chrystusa. Stąd Jan Paweł II pyta o dalszą drogę, którą m.in. dostrzega w kontynuowaniu i pogłębianiu dialogu ekumenicznego (por. UUS 77-79), bowiem wiele jeszcze problemów doktrynalnych pozostało do uzgodnienia i do rozwiązania. Przede wszystkim czeka na urzeczywistnienie recepcja dotychczasowych dialogów (UUS 80-81), polegająca na przyswojeniu sobie w trudzie wypracowanych doktrynalnych osiagnięć ${ }^{33}$.

33 Por. W. Hanc, Istotne elementy treściowe ekumenii w świetle papieskiej encykliki „Ut unum sint”, w: J. Warzecha (red.), Stowo pojednania, Warszawa 2004, s. 441; tenże, Ekumenizm Jana Pawła II, „Ateneum Kapłańskie” 133 (1999), z. 543-544, s. 213-220. 
Każdy ekumenista jest jednak świadom, że obecny etap dialogowych zmagań zmusza do zadumy nad problemem recepcji wypracowanych już dokumentów, bowiem nie można ich tylko układać w stos czy systematyzować w zależności od podejmowanych problemów związanych z taką lub inną dyscypliną teologiczna. Może dojść bowiem do paradoksalnej sytuacji, iż nagromadzenie dialogów i uzgodnień spowoduje uznanie dla uzgodnień ostatnich, jak to miało miejsce ze Wspólną Deklaracją katolicko-luterańską o usprawiedliwieniu, a zapoznanie ważnych - pierwszych dokumentów ${ }^{34}$. Jeżeli bierzemy na serio słowa arcykapłańskiej modlitwy Chrystusa (por. J 17, 21), a więc jedność Chrystusowego Kościoła i dobro nadal podzielonej rodziny chrześcijańskiej, to także i w problemie recepcji należy połączyć ekumeniczne wysiłki, by „wspólnie dawać świadectwo ewangelicznemu orędziu" (UUS 40) i wszystko czynić celem przyśpieszenia procesu recepcji wyników dialogu, czyli zapobiec wytwarzaniu się i powstawaniu tzw. próżni dialogowej. Nie można więc nie podzielać troski komentatorów encykliki Jana Pawła II Ut unum sint, kierowanej pod adresem kompetentnych władz poszczególnych Kościołów, by nie zwlekać z przyjęciem tego, co może być przyjęte $^{35}$. Dlatego warto zwrócić uwagę, choćby egzemplarycznie, na dwa zwiastuny ekumenicznej wiosny: na Wspólną katolicko-luterańską deklarację w sprawie nauki o usprawiedliwieniu (1999) oraz na niezwykłej wagi dokument zwany Karta ekumeniczna (2001).

\subsubsection{Wspólna deklaracja o usprawiedliwieniu}

Prawdą jest, iż wysiłki ekumeniczne wcześniejszych dziesięcioleci stały się podstawą dla coraz bardziej ważkich międzywyznaniowych uzgodnień doktrynalnych, a zarazem bodźcem dla dalszego, jeszcze bardziej zintensyfikowanego dialogu ekumenicznego. Przykładem tego jest wspólna „Deklaracja o usprawiedliwieniu", której nie można postrzegać i analizować bez kontekstu i tła całego dialogu luterańsko-katolickiego, prowadzonego już przecież od 45 lat, bowiem 7 lipca 1965 r. powołano Wspólną Grupę Roboczą złożoną z delegatów zaproszonych przez Rzymski Sekretariat do Spraw Jedności Chrześcijan oraz Światową Federację Luterańską (odtąd: ŚFL) ${ }^{36}$. Warto tu także nadmienić, iż metoda bilateralnych dialogów domaga się m.in., by

${ }^{34}$ Zob. W. Hanc, Od Vaticanum II do encykliki „Ut unum sint”, w: P. Jaskóła (red.), dz. cyt., s. 32-33.

${ }_{35}$ Tenże, Ekumeniczny, s. 65.

${ }^{36}$ Zob. S. C. Napiórkowski, Dialog, w: K. Karski, S. C. Napiórkowski (red.), Bliżej Wspólnoty. Katolicy i luteranie w dialogu 1965-2000, Lublin 2003, s. 17-19; K. Karski, Od Edynburga do Porto Alegre. Sto lat dażeń ekumenicznych, Warszawa 2007, s. 254-255. 
konkretne a zarazem specyficzne teologiczne kwestie i pytania, które dzielą obydwie tradycje wyznaniowe, nie tylko zostały możliwie wszechstronnie naświetlone, ale uwzględniały równocześnie problemy, które nie zyskały pełnej aprobaty obydwu stron i powinny być przedmiotem dalszych badań. Ponadto oficjalno-kościelny charakter dialogu ma prowadzić do osiagnięcia konkretnych wyników przejawiających się także w akceptacji ekumenicznych uzgodnień, potrzebnych do umocnienia życia Kościołów ${ }^{37}$. Przy czym, uwzględniając ewangelicki punkt patrzenia, podstawą ściślejszej wspólnoty i jedności, tyczącej się dialogujących stron, powinno być dążenie do zgodności poglądów w sprawach wiary ${ }^{38}$. Właśnie do takich trudnych prawd wiary różniących Kościół katolicki i Kościół ewangelicko-augsburski od prawie pięciu wieków należy problem usprawiedliwienia, gdzie już w samym dokumencie dialogowym i uzgodnionym tekście zapisano, że „przeciwstawna interpretacja i przeciwstawne zastosowanie orędzia biblijnego o usprawiedliwieniu były w XVI stuleciu głównym powodem podziału Kościoła zachodniego, co znalazło też swoje odbicie w potępieniach doktrynalnych" 39 .

Nie wchodząc w tym miejscu w przedmiot i korzenie sporu, trzeba dopowiedzieć, iż właściwie kwestia usprawiedliwienia była podejmowana bezpośrednio lub pośrednio podczas wszystkich czterech faz katolicko-luterańskiego dialogu ${ }^{40}$. Osadzając $w$ tym kontekście dokument trzeciej fazy

37 Por. DwÜ 1, s. 13-14.

${ }^{38}$ Por. K. Karski, Symbolika. Zarys wiedzyo Kościołach i Wspólnotach chrześcijańskich, Warszawa 2003, s. 165.

39 Jest to n. 13 Deklaracji. Całość Wspólnej Deklaracji, zob. EOe 7, Bologna 2006, s. 885-912 oraz Consenso sulla dottrina della giustificazione. Dichiarazione ufficiale comune e Allegato, tamże, s. 913-918. Tłumaczenie polskie w: K. Karski (red.), Deklaracja, s. 25 (cały tekst zawiera się na ss. 21-41). Tożsame teksty Deklaracji, zob. K. Karski, S. C. Napiórkowski (red.), dz. cyt., s. 499-523; A. Nossol, Ekumenizm jako imperatyw chrześcijańskiego sumienia. Przez dialog i pojednanie ku ekumenicznej jedności, Opole 2000, s. 243-254.

${ }^{40}$ Faza pierwsza dialogu miała miejsce w latach 1967-1972. Rozpoczęła się powołaniem w 1967 r. przez Watykański Sekretariat do Spraw Jedności Chrześcijan oraz ŚFL - Międzynarodowej Komisji Studiów, a zakończyła się w 1971 r. dokumentem podsumowującym, zwanym Raportem z Malty (Malta-Bericht), opublikowanym w 1972 r. Faza druga obejmuje lata 1973-1984, podczas których spośród sześciu opracowanych dokumentów trzy podejmują kwestie usprawiedliwienia: Wieczerza Pańska (1977), Wszyscy pod jednym Chrystusem (1980) oraz Marcin Luter, świadek Jezusa Chrystusa (1983). Faza trzecia (1986-1993) kończy się opublikowaniem Raportu końcowego nt. „,Kościót i usprawiedliwienie” (1993). I wreszcie podczas fazy czwartej (1995-2005) dochodzi do ostatecznego sformułowania i uroczystego podpisania Wspólnej Deklaracji w sprawie nauki o usprawiedliwieniu (1999). Por. K. Karski, Symbolika, s. 254-255. Ponadto o powyższych etapach dialogu katolicko-luterańskiego traktuje całość pracy wyżej cytowanej: K. Karski, S. C. Napiórkowski (red.), Bliżej Wspólnoty, Lublin 2003. Należy tu także nadmienić, iż problem usprawiedliwienia stał się przedmiotem dialogu, nie tylko w wymiarze międzywyznaniowym i międzynarodowym, lecz również w rozmowach lokalnych. 
(Kościół i usprawiedliwienie), należy wprost stwierdzić, iż od wieku XVI istniał ewidentny spór albo łagodniej mówiąc znaczące różnice pomiędzy reformatorami i katolikami w kwestii bądź co bądź podstawowego artykułu wiary, jakim jest articulus stantis et cadentis Ecclesiae, bowiem tak został określony artykuł wiary o usprawiedliwieniu, czyli artykuł, na którym się wspiera i stoi rzeczywistość Kościoła ${ }^{41}$.

I oto po ponad czterech wiekach kontrowersji niemożliwe staje się możliwe. Dnia 31 października 1999 r. została podpisana w tym samym mieście, w którym w 1530 roku podjęto pierwszą próbę pojednania, kiedy to Melanchton odczytał tzw. Konfesję Augsburska, Wspólna deklaracja. W imieniu Papieża dokument poświadczył kard. E. I. Cassidy - przewodniczący Papieskiej Rady do Spraw Jedności Chrześcijan, zaś w imieniu Kościołów członkowskich ŚFL - jej prezydent, bp Christopher Krause.

Uzgodniony dokument nie jest obszerny ${ }^{42}$, jednak zawiera niezwykłej wagi uzgodnienie o wręcz epokowym znaczeniu, gdyż osiagnięto konsens w podstawowych prawdach dotyczących nauki o usprawiedliwieniu, co pojawiało się w kilku miejscach ${ }^{43}$. Jednak w podpisanym dokumencie nie ukrywano odmiennych wrażliwości czy nadal pozostających różnic. Ówczesny prefekt Kongregacji Doktryny Wiary, kard. J. Ratzinger, domagał się mocniejszego podkreślenia owych różnic. Stąd strona katolicka opracowała dodatkowo zwięzły tekst, który przez obydwa Kościoły został uznany jako dopowiedzenie związane integralnie ze Wspólnq deklaracja w postaci Aneksu. Mimo wszystko należy powiedzieć, że został potwierdzony w na-

Dlatego należy tu także wymienić dwa inne dokumenty, które powstały w USA i w Niemczech, zyskując szczególną rangę. Są to: Raport „usprawiedliwienie przez wiarę” (1983) Wspólnej Komisji katolicko-luterańskiej w USA oraz Dokument studyjny: Czy potępienia doktrynalne maja charakter rozłamowo-kościelny? (1986) - dokument opracowany przez Ekumeniczną Grupę Teologów ewangelickich i katolickich w Niemczech. Zob. J. M. Lipniak, Ekumeniczne usprawiedliwienie podzielonych grzeszników, Świdnica 2006, s. 136-137; M. Hintz, Wspólna deklaracja w sprawie nauki o usprawiedliwieniu Światowej Federacji Luterańskiej i Papieskiej Rady do Spraw Jedności Chrześcijan (zmiany redakcyjne), „Studia i Dokumenty Ekumeniczne” 14 (1998), nr 1, s. 52.

${ }^{41}$ Zob. Dokument „Kościót i usprawiedliwienie”, „Studia i Dokumenty Ekumeniczne” 11 (1995), nr 2, s. 48, n. 2, przypis 1. Warto zwrócić tu także uwagę na podsumowanie dokonane przez T. Jaklewicza, Święty grzesznik. Formuła Marcina Lutra ,, simul iustus et peccator", w kontekście ekumenicznym, Lublin 2006, s. 120-123.

${ }^{42}$ Składa się ze Wstęp (art. 1-7) oraz z 37 dalszych artykułów skondensowanych w pięciu rozdziałach: 1) Biblijne orędzie o usprawiedliwieniu (art. 8-12);2) Nauka o usprawiedliwieniu jako problem ekumeniczny (art. 13); 3) Wspólne rozumienie usprawiedliwienia (art. 14-18); 4) Rozwinięcie wspólnego rozumienia usprawiedliwienia (art. 19-39) oraz 5) Znaczenie i zasięg osiagniętego konsensu. Odtąd skrót dokumentu: Wspólna Deklaracja, z podaniem odnośnych artykułów.

${ }^{43}$ Por. Wspólna Deklaracja, n. 5, 13, 14, 44. 
uce o usprawiedliwieniu osiagnięty konsens, choć stanowczo zasygnalizowano równocześnie najważniejsze różnice, które dotyczą, ogólnie mówiąc, czterech kwestii: zagadnienia współpracy z łaską (cooperatio), zagadnienia zasługi, sprawy natury usprawiedliwienia oraz zagadnienia antropologicznej zasady, iż człowiek jest równocześnie sprawiedliwy i grzeszny (simul iustus et peccator). Nie przybliżając $\mathrm{w}$ tym miejscu w szczegółach powyższych kwestii, ogólnie skonstatujmy, że czekają one na dalsze dialogowe rozpracowania i wyjaśnienia ${ }^{44}$. Należy tu także zaznaczyć, iż zdecydowana większość Kościołów przynależących do ŚFL udzieliła na Deklarację odpowiedzi pozytywnej (62 Kościoły) ${ }^{45}$, co było i pozostanie niezwykłym sukcesem na miarę przełomu.

W całym wymiarze zgodzić się trzeba $\mathrm{z}$ tenorem wypowiedzi o. prof. S. C. Napiórkowskiego, iż istnieją dwa źródła owego konsensu: Ewangelia i dialog. Ewangelia rodzi nadzieję, gdyż nie przestaje fascynować swą głębią i odmiennością, z jaką patrzy na nią człowiek nawet niewierzący. Z kolei dia$\log$ zdumiewa, stanowiąc klucz do owej tajemnicy, bowiem w dialogu chodzi o zwycięstwo prawdy, o słuszność, czyli o to, by zwyciężył Chrystus i Jego Ewangelia ${ }^{46}$. Dlatego warto zacytować stwierdzenie, iż ,podpisanie przez luteran i katolików konsensu w najważniejszej sprawie usprawiedliwienia, znaczy wielki przełom $w$ relacjach tych dwu wielkich nurtów chrześcijaństwa, a zatem również w kulturze Europy i świata chrześcijańskiego" "47.

Spośród pięciu rozdziałów Wspólnej deklaracji zasygnalizujmy w tym miejscu jej temat główny, czyli rozdział trzeci odnoszący się do „Wspólnego rozumienia usprawiedliwienia", stanowiący esse całego dokumentu, nad którego powstaniem pracowano w sumie ponad 30 lat, pokazując jak ,,miłość przeciera szlaki ku prawdzie" ${ }^{48}$. Dlatego tak ważne od strony treści wydaje się być to, co zostało jasno zawarte w artykule 15 Deklaracji: ,podzielamy wspólną wiarę, iż usprawiedliwienie jest dziełem Trójjedynego Boga. Bóg posłał na świat swojego Syna dla zbawienia grzeszników. Inkarnacja, śmierć i zmartwychwstanie Chrystusa są podstawą i warunkiem usprawiedliwienia. Usprawiedliwienie oznacza zatem, że sam Chrystus jest naszą sprawiedliwością, która staje się naszym udziałem z woli Ojca przez Ducha Świętego. Wyznajemy wspólnie: tylko z łaski i w wierze w zbawcze działanie Chrystusa, a nie na podstawie naszych zasług zostajemy przyjęci przez Boga i otrzy-

44 Zob. S. C. Napiórkowski, Bóg łaskawy, Warszawa 2001, s. 32-36. Natomiast sprawę „Aneksu”, jego historii i tekstu, zob. tamże, s. 36-43.

45 Zob. Uchwała Rady Światowej Federacji Luterańskiej z dnia 16 VI 1998 r., Aneks, w:

K. Karski (red.), Deklaracja, s. 51-52.

46 Por. S. C. Napiórkowski, Wierzę wjeden Kościót, Tarnów 2003, s. 204-206.

47 Tamże, s. 206.

48 Por. tenże, Bóg laskawy, s. 82-83. 
mujemy Ducha Świętego, który odnawia nasze serca, uzdalnia nas i wzywa do dobrych uczynków" (Wspólna deklaracja, n. 15).

Konkludując zaznaczmy, iż w podstawowych tak co do treści, jak i co do zakresu tezach dokonano niemal kopernikańskiego zwrotu. Pomimo pewnych zastrzeżeń, wysuwanych przez obydwie strony prowadzące dialog, osiagniętemu porozumieniu należy przypisać historyczne znaczenie na drodze luterańsko-katolickiej ekumenii, w czym upatruje się równocześnie niezwykły krok ku widzialnej jedności Kościoła. Wyraził to sam papież Jan Paweł II w przemówieniu do prezydenta ŚFL Christofera Krause, który gościł na zaproszenie Papieża i Papieskiej Rady do Spraw Jedności Chrześcijan w dniach 8-11 grudnia 1999 r. w Rzymie, a więc w kilka tygodni po podpisaniu Wspólnej deklaracji: „Dziękujemy Bogu, że umożliwił nam uczynić milowy krok na niełatwej drodze przywracania pełnej jedności między chrześcijanami”" ${ }^{49}$. Według polskich znawców tej problematyki: „ten dokument [...] jest wielkim darem Ducha dla Kościoła" (A. A. Napiórkowski) ${ }^{50}$, zaś w ujęciu S. C. Napiórkowskiego wcale nie jest on - jak niektórzy sądzili - ,zdradą tożsamości” czy relatywizacją prawdy ${ }^{51}$. Z kolei w refleksji polskiego teologa ewangelickiego M. Hintza uzyskany dokument „Dla luteran jest [...] istotnym tekstem budującym tożsamość wyznaniową w ramach Światowej Federacji Luterańskiej, tekstem przypominającym wielu członkom Kościoła i teologom, co jest prawdziwym dziedzictwem reformacji i co pozostaje prawdziwym fundamentem dla tej tradycji teologicznej" 52 .

Po pięciu latach od podpisania Wspólnej deklaracji, w liście z lipca 2004 r. ks. dr Ishmael Noko, sekretarz generalny ŚFL, oraz kard. Walter Kasper, przewodniczący Papieskiej Rady do Spraw Jedności Chrześcijan, wspólnie stwierdzili, że dokument ten ,jest dla nas okazją, by nadal czerpać ze Wspólnej deklaracji w sprawie nauki o usprawiedliwieniu jako z ekumenicznego źródła. Kościołom i diecezjom na całym świecie daje ona możliwość wnoszenia własnego wkładu do toczącej się dyskusji nad nierozwiązanymi kwestiami i towarzyszącymi im wyzwaniami" ${ }^{53}$.

${ }^{49}$ Cyt. za tekstem przemówienia, „Studia i Dokumenty Ekumeniczne” 16 (2000), nr 1, s. 127 i 128.

${ }^{50}$ A. A. Napiórkowski, Bogactwo łaski a nędza grzesznika. Zróżnicowany konsens teologii katolickiej i luterańskiej o usprawiedliwieniu osiagnięty $w$ dialogu ekumenicznym, Kraków 2000, s. 298.

${ }^{51}$ Por. S. C. Napiórkowski, Wierzę w jeden Kościót, s. 204: „Uczestniczyłem w tym dialogu. Z całym przekonaniem protestuję przeciwko oskarżeniom o zdradę Ewangelii czy o zdradę własnej tożsamości Kościołów”.

${ }_{52}$ M. Hintz, dz. cyt., s. 60.

${ }^{53}$ Luteranie i katolicy. Piata rocznica podpisania Wspólnej Deklaracji w sprawie nauki o usprawiedliwieniu, ,Studia i Dokumenty Ekumeniczne” 21 (2005), nr 1-2, s. 115. 
Nie sposób nie zacytować wreszcie - pro domo sua - oświadczenia ówczesnego przewodniczącego Ekumenicznej Rady Konferencji Episkopatu Polski, abpa A. Nossola: „Wspólna Deklaracja jest podstawą optymistycznego spojrzenia Kościoła Chrystusowego w przyszłość [...] jest pierwszym dokumentem ekumenicznym zaakceptowanym na najwyższym szczeblu i podpisanym z zobowiązaniem do przyjęcia przez dwa Kościoły"54.

I tak, długotrwający niełatwy dialog doktrynalny, odnoszący się do sedna niezwykle ważnego dla ekumenizmu problemu teologicznego, idący w kierunku ,prawdy w miłości”, przynosi zasadnicze uzgodnienie w kwestii najważniejszego artykułu wiary, na którym opiera się Kościól. Zakończony przez to został długotrwały i tragiczny dla chrześcijaństwa okres w dziejach katolików i luteran ${ }^{55}$. Osiagnięty konsens ma nie tylko istotny wymiar doktrynalny, ale i duchowy ${ }^{56}$, tyczący się całego chrześcijaństwa, co napawa niezwykłym optymizmem i nadzieją tak w odniesieniu do dwu dialogujących z sobą tradycji wyznaniowych, jak i odnośnie do wszystkich wierzących w Chrystusa, tym bardziej, że Wspólnq deklarację uznały dwa dalsze ewangelickie Kościoły: Kościół reformowany i Kościół metodystyczny.

\subsubsection{Karta ekumeniczna - spojrzeniem w przyszlość}

Kolejnym przykładem znaku nadziei dla chrześcijaństwa jest Karta ekumeniczna (22 IV 2001), która już w podtytule zawiera ukierunkowanie na przyszłość: Wytyczne dla wzrastajacej wspótpracy pomiędzy Kościołami w Europie $^{57}$. Dokument jest wspólnym owocem kilkuletnich konsultacji dokonywanych w łonie Katolickich Konferencji Episkopatów oraz Kościołów członkowskich KEK, w wyniku czego sformułowano wytyczne, reguły i kryteria, mogące stać się pomocą i skutecznym środkiem do międzywyznaniowej współpracy, a zarazem jeszcze bardziej zintensyfikowanego dialogu

${ }^{54}$ A. Nossol, Kościół Chrystusowy ma przyszłość, „Studia i Dokumenty Ekumeniczne” 21 (2005), nr 1-2, s. 116.

${ }^{55}$ Cyt. za: J. M. Lipniak, dz. cyt., s. 198.

56 Zob. A. A. Napiórkowski, dz. cyt., s. 314.

${ }^{57}$ Tekst polski Karty Ekumenicznej został przygotowany wspólnie przez Radę Episkopatu do Spraw Ekumenizmu Kościoła rzymskokatolickiego oraz Polską Radę Ekumeniczną (PRE). Tekst podpisali wspólnie abp A. Nossol, przewodniczący Rady Episkopatu oraz abp Jeremiasz, prezes PRE w dniu 25 II 2003 r. Zamieszczony także został tekst oryginalny w języku niemieckim, opublikowany i podpisany w Strasburgu 22 IV 2001 r. przez metropolitę Jeremiasza, przewodniczącego Rady Konferencji Kościołów (skrót: KEK), oraz kard. Vlka, przewodniczącego Rady Konferencji Episkopatów Europy (skrót: CCEE). 
ekumenicznego, popartego recepcją wypracowywanych dokumentów ${ }^{58}$. Jest to pierwszy tego rodzaju dokument noszący znamię wezwania skierowanego do wszystkich chrześcijan, by włączyli się „w nowy proces odnowy ekumenicznej kultury dialogu i współpracy między Kościołami” z jednoczesnym dostarczeniem w tym celu zobowiązującej normy. Dokument stanowi także zachętę do pogłębienia duchowej wspólnoty z innymi religiami monoteistycznymi (judaizm, islam), a także do podjęcia dialogu $\mathrm{z}$ wyznawcami innych religii i światopoglądów, z równoczesnym wykluczeniem ideologii ${ }^{59}$. W oparciu o wspólną wiarę w Chrystusa Karta ekumeniczna ukazuje drogę wzajemnego zbliżenia się do siebie, wychodząc od tego, co chrześcijan łączy, wzywając zarazem do szacunku dobrowolnego wyboru przynależności religijnej i kościelnej, przeciwstawiając się wszelkim formom prozelityzmu ${ }^{60}$. Ważne jest też dla Europejczyków stwierdzenie, iż „Kościoły popierają jednoczenie się kontynentu europejskiego", co powinno się urzeczywistniać na fundamencie wiary chrześcijańskiej i duchowych wartości, pośród których wymienić trzeba: prawa człowieka oraz takie podstawowe wartości jak: pokój, sprawiedliwość, wolność, tolerancja, dzielenie się z ubogimi, poszanowanie życia, ratowanie stworzenia, przebaczenie i miłosierdzie ${ }^{61}$.

CCEE oraz KEK zobowiązały się w duchu dwu Europejskich Zgromadzeń Ekumenicznych w Bazylei (1989) i w Grazu (1997) strzec i rozwijać wspólnotę, która już została wytworzona, oraz z pomocą Ewangelii angażować się ,na rzecz godności osoby ludzkiej stworzonej na obraz i podobieństwo Boga”, zaś ,jako Kościoły przyczyniać się wspólnie do pojednania narodów i kultur" $" 62$.

Tekst Karty, począwszy od zarysowanego już w 1999 r. projektu ${ }^{63}$, przechodził pewną ewolucję, na co nie była bez wpływu swoistego rodzaju ankieta w postaci sześciu punktów, które wraz z projektem roboczym, opracowanym w Cartigny k. Genewy przesłano w lipcu 1999 r. Kościołom członkowskim KEK oraz krajowym Konferencjom Episkopatów Europy. Do dyskusji na temat Karty usiłowano wciagnąć możliwie dużą liczbę diecezji, parafii, a nawet

${ }^{58}$ Por. Wprowadzenie, w: Karta Ekumeniczna, Warszawa 2003, s. 3, oraz bezpośrednie wprowadzenie do Ekumenicznej Karty, tamże, s. 7. W odwołaniach do Karty używane będzie thumaczenie zaakceptowane przez Radę Episkopatu do Spraw Ekumenizmu i Polską Radę Ekumeniczną w wyżej zasygnalizowanym wydaniu z 2003 r., podając kursywą tytuł dokumentu. 2002, s. 5 .

${ }^{59}$ L. Górka, Wprowadzenie, w: Karta Ekumeniczna (Charta Oecumenica), Lublin

${ }^{60}$ Por. tamże.

${ }^{61}$ Tamże, s. 5-6.

${ }^{62}$ Karta Ekumeniczna, s. 6-7.

${ }^{63}$ Genewa/ST. Gallen, lipiec 1999 r., zob. Karta Ekumeniczna (Charta Oecumenica), s. 7-22. 
konkretnych grup kościelnych. Projekt Karty został przetłumaczony na 20 języków europejskich, zaś jego treści poświęcono wiele debat, spotkań i konferencji, i to tak w skali lokalnej, krajowej, jak i międzynarodowej. W sumie władze KEK i CCEE otrzymały 150 odpowiedzi, zawierających komentarze, uwagi i propozycje zmian. Komitet redakcyjny Karty obradujący w Genewie (30 IX - 3 X 2000) przystapił do opracowania nowej wersji tekstu, co zostało przedłożone i zaaprobowane przez wspólny Komitet KEK i CCEE w styczniu 2001 r. Uroczystość podpisania odbyła się w tydzień po Wielkanocy wspólnie już obchodzonej przez chrześcijan Wschodu i Zachodu. Okazją po temu było Europejskie Spotkanie Ekumeniczne zwołane do Strasburga (Francja) w dniach od 17 do 22 kwietnia 2001 roku $^{64}$.

Karta ekumeniczna usiłowała odpowiedzieć m. in. na kilka ważnych kwestii: jak zbudować europejski „dom” zdolny objąć gościnnością różne narody, kultury, religie, nie niszcząc ich tożsamości; jak przejąć odpowiedzialność za problemy nękające ludzkość; w jaki sposób powinny się odnaleźć Kościoły chrześcijańskie w społeczeństwie naznaczonym kulturowym, etycznym i religijnym pluralizmem; jak odnieść się do wielkich tematów etycznych oraz jaką dawać odpowiedź na pytania o sens miłości, sens życia, zwłaszcza w obliczu cierpienia i śmierci ${ }^{65}$.

I chociaż sam tekst dokumentu nie jest długi ${ }^{66}$, to jednak co do rangi i zawartych w nim przesłań jest bezprecedensowy, otwierający przed Kościołami Europy nowe przestrzenie na polu ekumenicznych przedsięwzięć. Otóż, obok stwierdzeń merytorycznych, tyczących się tematyki zawartej w poszczególnych rozdziałach, zawiera przy końcu każdego z analizowanych punktów ważne zobowiązania głównie dla kultury dialogu i międzywyznaniowej współpracy, co otwiera przed chrześcijańską Europą niezwykle cenną wizję zintegrowanej Europy, u podstaw czego stoi konieczność kontynuacji „starań zmierzających do zgody opartej na wierze. Bez jedności w wierze nie istnieje pełna wspólnota kościelna. Nie ma żadnej alternatywy dla dialogu". Dlatego należy „sumiennie i intensywnie kontynuować dialog na różnych płaszczyznach życia kościelnego oraz spowodować, co może i powinno zostać oficjalnie uznane przez Kościoły za obowiązujący wynik dialogu"67.

${ }^{64}$ Por. K. Karski, Milowy krok ekumenii-podpisanie Karty Ekumenicznej, w: Ewangelizacja i tożsamość, Kalendarz Ewangelicki 2002, s. 250-251.

${ }^{65}$ L. Górka, Komentarz do Charta Oecumenica, w: Karta Ekumeniczna (Charta Oecumenica), s. 39.

${ }^{66}$ Składa się z trzech rozdziałów: I. Wierzymy w ,jeden, święty, katolicki i apostolski Kościót”, II. Na drodze ku widzialnej wspólnocie Kościołów w Europie, III. Nasza wspólna odpowiedzialność w Europie. Rozdziały zostały poprzedzone wprowadzeniem i krótkim zakończeniem, na co złożyło się w sumie 12 punktów tekstu zamieszczonych na 12 stronach formatu A 6 .

${ }^{67}$ Karta Ekumeniczna, n. 6, s. 12. 
Nie można na koniec nie stwierdzić, iż Karta ekumeniczna otwiera przed Europa, w tym i przed Polską, nowy kierunek, tchnący nadzieją ku podejmowaniu w trzecim tysiącleciu konkretnych nowych zadań dialogowych, niwelujących różnice a przybliżających moment pełnej jedności w wierze, sakramentach i we wspólnym posługiwaniu.

W miejsce podsumowania kilka refleksji jednego z najwybitniejszych polskich ekumenistów nadziei - prof. Wacława Hryniewicza (OMI), który w swojej „wierze w sens dążeń ekumenicznych” m.in. pisze:

Wizja ludzkości ostatecznie pojednanej kiedyś w Bożym Królestwie przynagla już teraz do przezwyciężania podziałów. Żaden wysiłek nie jest daremny. Każda dobra inicjatywa ma swoje znaczenie; wszystko to, co ostatecznie nadaje sens wszelkiemu dobru i pięknu, które urzeczywistnia się w dziejach tej ziemi. Choćby w ciagu doczesnej historii chrześcijaństwo nigdy nie zdołało osiagnąć całkowitego pojednania i widzialnej jedności, dążenie do niej jest obowiązkiem i powinnością wszystkich. Ludzkim wysiłkom przyświecać będzie zawsze nadzieja, iż dzięki modlitwie pokoleń oraz nieustannym wysiłkom przezwyciężone zostaną kiedyś przynajmniej wielkie historyczne podziały.

Sytuacja obecna wysoce kompromituje świadectwo chrześcijańskie. Niezgoda i podziały nie muszą trwać aż do dnia zmartwychwstania. Wierzę w sens wysiłków zmierzających do pojednania Kościołów [...]. Tą nadzieją żyję i usiłuję dawać jej świadectwo ${ }^{68}$.

Całość zaś niniejszych refleksji zakończmy następującą konkluzją: nie można w kontekście nadziei nie popierać i nie kontynuować dialogu ekumenicznego oraz wzajemnego poznawania się i darzenia szacunkiem, bowiem chodzi o jedno, by w ten sposób dążyć do pełnej jedności, czego pragnął Jan Paweł II, a póki co: trzeba budować chrześcijaństwo coraz bardziej godne wierzących.

${ }^{68}$ W. Hryniewicz, Pedagogia nadziei. Medytacje o Bogu, Kościele i ekumenii, Warszawa 1997, s. 122-123. 


\section{Il dialogo ecumenico - i segni della speranza per il cristianesimo (Riassunto)}

Sia ecumenismo che il suo elemento essenziale cioè il dialogo ecumenico, dopo più di 40 anni e dopo una centinaia dei documenti elaborati nei colloqui bilaterali, devono essere visti come segni dei tempi moderni ma soprattutto come segni della speranza per un cristianesimo sempre più unito anche se paradossalmente in questo momento ancora diviso. Inoltre il centesimo anniversario dell'inizio del movimento ecumenico celebrato quest'anno (Edinburgo - 1910) ci fa guardare con l'ottimismo nel futuro e considerare ogni agire ecumenico come "un imperativo della coscienza cristiana illuminata dalla fede e guidata dalla carità" (Giovanni Paolo II, $U t$ unum sint, n. 8). Quest'affermazione prima di tutto si riferisce al dialogo ecumenico iscritto nel cuore degli sforzi ecumenici perché qui non si parla soltanto del dialogo dottrinale ma anche di queste sue impostazioni come: dialogo in quanto esame di coscienza, dialogo di conversione, carità e riconciliazione. In conseguenza tale dialogo dovrebbe condurre al dialogo della salvezza perché il concetto di "dialogo" come tale significa sia scambio delle idee sia, in certo senso, "scambio di doni" (Ut unum sint, n. 28) che secondo Giovanni Paolo II può portare al nuovo e fruttuoso "varcare la soglia di speranza".

Al riguardo particolarmente i santi e i martiri provenienti da varie chiese e comunità ecclesiali hanno dato la loro testimonianza. Questa testimonianza non può essere dimenticata perché anche "nel nostro secolo sono ritornati i martiri. La communio sanctorum parla con voce più alta dei fattori di divisione" (Tertio millennio adveniente, n. 37). I santi come persone del dialogo continuo con Dio e con gli altri, soprattutto i martiri che sigillano con sacrificio la loro vita, sono i segni straordinari di speranza confermanti la necessità del riunirsi accanto a Cristo attraversando ogni barriera della confessione perché "tutti crediamo nello stesso Dio anche se in modo diverso" (K. Barth). Seguendo il pensiero di Giovanni Paolo II occorre trovare nei santi i raggi luminosi per il futuro del cristianesimo e la motivazione per continuare e recepire il dialogo ecumenico.

Ognuno che segue lo sviluppo del dialogo dottrinale chiamato a volte "il nodo gordiano del ecumenismo" è cosciente delle difficoltà incontrate, legate non solo al sentiero dell'esporre i punti comuni ma anche dei problemi rimasti fuori dialogo, innanzitutto riguardanti la ricezione delle soluzioni in campo di teologia. Ci sono però i momenti pieni di ottimismo che si riferiscono ai frutti raggiunti, prima di tutto a due documenti (approvati dai superiori ambienti ecclesiastici) costituenti signa prognostica che bisogna prendere in considerazione. Il primo, "Dichiarazione congiunta sulla dottrina della giustificazione" che si riferisce al dialogo cattolicoluterano, dimostra la possibilità del concordare nel tema così controverso dai tempi della Riformazione - della giustificazione che è articulus stantis et cadentis Eccle- 
siae (il documento approvato il 31.10.1999 a Augsburgo); l'altro, nello stesso tempo divenuto un altro segno di speranza per i cristiani in Europa è "La carta ecumenica" (approvata il 22.04.2001 a Strasburgo) che indica la via di collaborazione tra le chiese in Europa. Quel documento ha dato risposta ad alcuni problemi presentati nell'articolo.

Alla fine bisogna sottolineare che l'articolo soltanto tocca alcuni aspetti del tema scelto indicando che "impossibile, nel dialogo diventa possibile" e che davanti al cristianesimo di varie confessioni nasce la speranza; che il "fare verità nell'amore" non ci fa aspettare la piena unità tra i cristiani fino ai tempi escatologici. Inoltre, "agire e soffrire sono i luoghi di apprendimento della speranza" (cfr. Benedetto XVI, Spe salvi, n. 35-40). 
